\title{
The protistan parasite Perkinsus marinus is resistant to selected reactive oxygen species
}

Article in Experimental Parasitology · November 2003

DOI: 10.1016/j.exppara.2003.12.012 · Source: PubMed

CITATIONS

44

4 authors, including:
READS

\section{Eric J Schott}

University of Maryland Center for Environme... 61 PUBLICATIONS 982 CITATIONS

SEE PROFILE

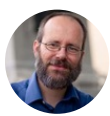

\section{Wolf T Pecher}

University of Baltimore

17 PUBLICATIONS 112 CITATIONS

SEE PROFILE

\section{Gerardo R Vasta}

University of Maryland, Baltimore

220 PUBLICATIONS $\quad 6,701$ CITATIONS

SEE PROFILE

Some of the authors of this publication are also working on these related projects:

Project

Variation in life history and connectivity as drivers of pathogen-host dynamics and genetic structure in a trans-hemispheric pathosystem View project

All content following this page was uploaded by Eric J Schott on 01 March 2016. 


\title{
The protistan parasite Perkinsus marinus is resistant to selected reactive oxygen species
}

\author{
Eric J. Schott, Wolf T. Pecher, Florence Okafor, and Gerardo R. Vasta* \\ Center of Marine Biotechnology, University of Maryland Biotechnology Institute, 701 East Pratt Street, Baltimore, MD 21202, USA
}

Received 2 June 2003; received in revised form 10 December 2003; accepted 12 December 2003

\begin{abstract}
The parasite Perkinsus marinus has devastated natural and farmed oyster populations along the Atlantic and Gulf coasts of North America. When viable $P$. marinus trophozoites are engulfed by oyster hemocytes, the typical accumulation of reactive oxygen species (ROS) normally associated with phagocyte activity is not observed. One hypothesis to explain this is that the parasite rapidly removes ROS. A manifestation of efficient ROS removal should be a high level of resistance to exogenous ROS. We investigated the in vitro susceptibility of $P$. marinus to ROS as compared to the estuarine bacterium Vibrio splendidus. We find that $P$. marinus is markedly less susceptible than $V$. splendidus to superoxide and hydrogen peroxide $\left(\mathrm{H}_{2} \mathrm{O}_{2}\right)$, but equally sensitive to hypochlorite. Viable $P$. marinus trophozoites degrade $\mathrm{H}_{2} \mathrm{O}_{2}$ in vitro, but lack detectable catalase activity. However, extracts contain an ascorbate dependent peroxidase activity that may contribute to $\mathrm{H}_{2} \mathrm{O}_{2}$ removal in vitro and in vivo.
\end{abstract}

(C) 2003 Published by Elsevier Inc.

Keywords: Alveolata; Hydrogen peroxide; Hypochlorite; Oxidative stress; Peroxidase; Perkinsus marinus; Superoxide; Vibrio splendidus

\section{Introduction}

The intracellular protistan parasite Perkinsus marinus is responsible for drastic declines in the eastern oyster (Crassostrea virginica) populations along the Atlantic and Gulf coasts of North America (Perkins and Menzel, 1967). Worldwide, there are multiple Perkinsus species associated with diseases of economically important bivalves (Azevedo, 1989; Lester and Davis, 1981). $P$. marinus shares structural and molecular characteristics with both the Apicomplexa and the Dinozoa (Goggin and Barker, 1993; Levine, 1978; Siddal et al., 1997), and recent molecular analyses indicate that Perkinsus is basal to, but not within, the dinoflagellate lineage (Saldarriaga et al., 2001), and a new phylum, the Perkinsozoa, has been established to include the genera Perkinsus, Parvilucifera, and Cryptophagus (Brugerolle, 2002; Norén et al., 1999). Some oyster species, such as Crassostrea gigas, are apparently resistant to $P$. marinus infections (Meyers et al., 1991), but are susceptible to

\footnotetext{
${ }^{*}$ Corresponding author. Fax: 1-410-234-8896.

E-mail address: vasta@umbi.umd.edu (G.R. Vasta).
}

other pathogens, such as the estuarine bacterium Vibrio splendidus (Lacoste et al., 2001), although the molecular basis of these differences is not understood.

Perkinsus marinus infections likely occur after ingestion of trophozoites or zoospores by filter feeding, followed by their engulfment by oyster hemocytes, and systemic dissemination (Perkins, 1996). Intrahemocytic survival and proliferation of $P$. marinus is believed to rely on its ability to abrogate the deleterious effects of reactive oxygen species (ROS) typically generated by the host hemocyte upon phagocytosis of biotic or abiotic particles. Like neutrophils of vertebrates, oyster hemocytes produce superoxide by an NADPH oxidase complex associated with the plasma membrane (Takahashi and Mori, 2000). In turn, superoxide is converted to hydrogen peroxide $\left(\mathrm{H}_{2} \mathrm{O}_{2}\right)$ by superoxide dismutases (SODs), and in the presence of chloride ion, $\mathrm{H}_{2} \mathrm{O}_{2}$ is the substrate for the production of hypochlorite $(\mathrm{HOCl})$, in a reaction catalyzed by myeloperoxidase (MPO) (Anderson et al., 1992; Greger et al., 1995). Cytotoxic effects of ROS include peroxidation of lipids, breakage of DNA strands, and inactivation of enzymes, especially those containing $\mathrm{Fe}-\mathrm{S}$ centers (Birnboim and Sandhu, 
1997; Brawn and Fridovich, 1981; Gardner and Fridovich, 1991). Compared to superoxide, $\mathrm{H}_{2} \mathrm{O}_{2}$ is relatively stable and able to diffuse rapidly across membranes (Ohno and Gallin, 1985). Hypochlorite is well known for its ability to damage membranes and cause cell rupture, as well as damage DNA and proteins (Dukan et al., 1999; Vissers et al., 1994). Although various molecules are efficient scavengers of $\mathrm{HOCl}$ (e.g., arginine, thiol-containing proteins, ascorbate; Ferrante et al., 1987; $\mathrm{Hu}$ et al., 1993), there is no enzymatic mechanism for its destruction.

Engulfment of live $P$. marinus trophozoites by oyster hemocytes does not result in the accumulation of appreciable quantities of ROS (Nakamura et al., 1985; Perkins, 1996; Volety and Chu, 1995), and limited parasite killing is observed (La Peyre et al., 1995). In contrast, phagocytosis of either heat- or osmotically killed $P$. marinus cells elicits a robust ROS response, suggesting that labile factors from live $P$. marinus are responsible (Anderson, 1999). Two hypotheses, not mutually exclusive, can be proposed: (a) P. marinus actively inhibits the ability of hemocytes to generate ROS, or (b) $P$. marinus degrades the host-generated ROS at a rate sufficient to prevent their accumulation and detection. If the latter is true, it would be expected that $P$. marinus is relatively tolerant to in vitro exposure to ROS. To investigate this possibility, we undertook experiments to examine the relative sensitivity of $P$. marinus to ROS, as compared to that of $V$. splendidus, which is associated with disease in the pacific oyster, C. gigas (Lacoste et al., 2001).

\section{Materials and methods}

\subsection{Reagents and cell culture}

Arginine, ethidium bromide, $\mathrm{H}_{2} \mathrm{O}_{2}$, xanthine, $\mathrm{NaOCl}$, fluorescein diacetate, neutral red, and Aspergillus niger catalase were obtained from Sigma (St. Louis, MO); xanthine oxidase was obtained from Calbiochem (La Jolla, CA). P. marinus strain Texas (ATCC 50849), was grown at $28^{\circ} \mathrm{C}$ in DMEM:Hams F12 (Sigma) with 5\% fetal bovine serum (Paragon, Baltimore, MD) and $15 \mathrm{ppt}$ artificial seawater (ASW; Instant Ocean, Mentor, OH) (Gauthier and Vasta, 1993). Bacterial strains $V$. splendidus (ATCC 33125) and Vibrio salmonicida (ATCC 43839) were maintained on LB agar (Difco, Detroit MI) at $22^{\circ} \mathrm{C}$.

\subsection{Reactive oxygen exposures}

Cultured $P$. marinus trophozoites, washed once in PBS500 (500 mM NaCl, $\left.20 \mathrm{mM} \mathrm{NaPO}_{4}, \mathrm{pH} 7.2\right)$ and suspended to a final $\mathrm{OD}_{600}$ of 0.025 , were exposed to ROS for $1 \mathrm{~h}$ in a total volume of $0.8 \mathrm{ml}$ in 24 -well tissue culture plates. All ROS-generating reagents were also diluted in PBS500. Exposure to superoxide-generating xanthine oxidase (XO) was accomplished by aliquoting $0.4 \mathrm{ml}$ of a trophozoite suspension (at $\mathrm{OD}_{600}$ of 0.05 ) into triplicate wells, followed by $0.2 \mathrm{ml}$ of $5 \mathrm{mM}$ xanthine, then $0.2 \mathrm{ml}$ of the appropriate $\mathrm{XO}$ stocks to yield final concentrations of $100,200,500$, and $1000 \mathrm{U} / \mathrm{ml}$. Confirmation of superoxide production by $\mathrm{X} / \mathrm{XO}$ was achieved using the water-soluble tetrazolium WST-1 (Dojindo Molecular Technologies, Gaithersburg, MD), at $430 \mathrm{~nm}$, following the method of Tan and Berridge (2000). By this method the rate of WST-1 reduction was linear from 5 to 110 , and a $25 \mathrm{mU} / \mathrm{ml}$ reaction created $5.3 \mu \mathrm{M} / \mathrm{min}$ superoxide (results not shown). The theoretical yield of superoxide from $25 \mathrm{mU} / \mathrm{ml}$ is $25 \mu \mathrm{M} / \mathrm{min}$; however, our assay conditions differ from those reported elsewhere (Bortolussi et al., 1987). Exposure of trophozoites to $\mathrm{H}_{2} \mathrm{O}_{2}$ and $\mathrm{HOCl}$ were similarly conducted by mixing $2 \times$ stocks of trophozoites with $2 \times$ solutions of either $\mathrm{H}_{2} \mathrm{O}_{2}$ or $\mathrm{HOCl}$. ROS exposures were terminated by pelleting cells by centrifugation at $450 g$, followed by two washes with sterile ASW. Trophozoites exposed to $\mathrm{HOCl}$ were washed first with ASW containing the radical scavenger arginine $(1 \mathrm{mM})$, then washed again with ASW. Cells were then suspended in culture medium and allowed to rest for $1 \mathrm{~h}$ before removing samples for viability assessments.

Vibrio splendidus were grown overnight on LB agar, harvested, and washed once in PBS500, then exposed to superoxide-generating xanthine oxidase $(\mathrm{X} / \mathrm{XO})$ activity in a manner similar to that described by Bortolussi et al. (1987). Briefly, $50 \mu \mathrm{l}$ of a suspension of bacteria at a calculated $\mathrm{OD}_{600}$ of 0.01 was aliquoted into triplicate wells of a 96-well microtiter plate, followed by $25 \mu \mathrm{l}$ of $5 \mathrm{mM}$ xanthine, then $25 \mu \mathrm{l}$ of a XO stock to yield final concentrations of $0,5,25,100$, and $200 \mathrm{mU} / \mathrm{ml}$ total per well. Additional ROS exposures were conducted by adding $50 \mu \mathrm{l}$ of a $2 \times$ stock of $\mathrm{H}_{2} \mathrm{O}_{2}$ or $\mathrm{HOCl}$ to $50 \mu \mathrm{l}$ of a $2 \times$ suspension of bacterial cells. Exposures were allowed to proceed for $60 \mathrm{~min}$ at room temperature, then arrested by 10 -fold dilution with ice-cold artificial sea water (ASW), followed by dilution-plating for CFUs. For $\mathrm{HOCl}$ treatments, arginine $(1 \mathrm{mM})$ was incorporated in the 10-fold ASW diluent (Ferrante et al., 1987).

\subsection{Viability assays}

Viability of $P$. marinus was determined by differential staining with $3 \mu \mathrm{M}$ fluorescein diacetate (FDA) and $0.01 \mathrm{mg} / \mathrm{ml}$ ethidium bromide (EtBr) (Rotman and $\mathrm{Pa}-$ permaster, 1966), and examination by fluorescence microscopy. Dead cells were indicated by red fluorescence, live cells by green fluorescence. FDA/EtBr staining was adequate for viability assessments of $\mathrm{X} / \mathrm{XO}$ - and $\mathrm{HOCl}-$ treated cells, but $\mathrm{H}_{2} \mathrm{O}_{2}$ treatments above $1 \mathrm{mM}$ caused P. marinus cells to become transiently FDA negative for 
up to $12 \mathrm{~h}$. The vast majority later regained FDA staining but not $\mathrm{EtBr}$ staining, indicating that they were not dead. Therefore, in $\mathrm{H}_{2} \mathrm{O}_{2}$ experiments, cells not staining with $\mathrm{EtBr}$ were counted as viable. As a confirmation that FDA negative, EtBr negative cells were viable, some experiments were also monitored with neutral red $(0.01 \%)$ staining; $16 \mathrm{~h}$ following $\mathrm{H}_{2} \mathrm{O}_{2}$ treatments, parallel staining with FDA and neutral red showed that both measures of viability were in agreement (data not shown). Viability of Vibrio strains was determined by serial dilution and plating on LB agar. Colonies were counted after $18-24 \mathrm{~h}$ incubation at $22^{\circ} \mathrm{C}$.

\subsection{Peroxide destruction assays}

The ability of live $P$. marinus and $V$. splendidus cells to remove hydrogen peroxide from solution was tested by suspending freshly harvested cells in PBS500, at $\mathrm{OD}_{600}$ of 2.0 and 0.025 , respectively. Cells were challenged with $75 \mu \mathrm{M} \mathrm{H}_{2} \mathrm{O}_{2}$ in triplicate reactions in microtiter wells ( $200 \mu \mathrm{l}$ final volume) at $22^{\circ} \mathrm{C}$. Samples were withdrawn at 20,40, and $60 \mathrm{~min}$, and assayed for remaining $\mathrm{H}_{2} \mathrm{O}_{2}$ using a microtiter adaptation of the FOX assay of Jiang et al. (1992). Standard curves were constructed using the same reagents as used for experiments. Viability of $P$. marinus and $V$. splendidus cells, after $1 \mathrm{~h}$ exposure to peroxides, was assessed by neutral red staining and dilution plating on LB, respectively.

For analysis of $\mathrm{H}_{2} \mathrm{O}_{2}$ destruction by cytosolic cell extracts, both $P$. marinus and $V$. splendidus were lysed in low osmotic buffer $\left(25 \mathrm{mM} \mathrm{NaPO}_{4}, \mathrm{pH} 7.2\right)$ containing $0.5 \%$ Triton $\mathrm{X}-100$. Cell debris was removed by centrifugation $(10,000 \mathrm{~g})$, and supernatants dialyzed overnight $\left(4{ }^{\circ} \mathrm{C}\right)$ against $0.5 \mathrm{M} \mathrm{NaCl}$ buffered with $25 \mathrm{mM} \mathrm{NaPO}_{4}$, $\mathrm{pH} 7.2$, and containing $1 \mathrm{mM}$ ascorbic acid (ASA). ${ }^{1} P$. marinus and $V$. splendidus extracts were processed in parallel, and maintained no more than $24 \mathrm{~h}$ at $0{ }^{\circ} \mathrm{C}$ until assayed. Ten microliters of extract was assayed in reaction conditions identical to those described for live cells. FOX assays were conducted on $10 \mu \mathrm{l}$ aliquots at $22^{\circ} \mathrm{C}$ in a final volume of $200 \mu \mathrm{l}$.

Ascorbate peroxidase assays were conducted essentially as described by Amako et al. (1994). Ten microliter aliquots of dialyzed $P$. marinus or $V$. splendidus extract were added to a reaction mixture of $0.2 \mathrm{mM}$ ASA in $25 \mathrm{mM} \mathrm{NaPO}_{4}, \mathrm{pH} 7.2$, mixed, and allowed to equilibrate for $15 \mathrm{~s}$. Five microliters of a $10 \mathrm{mM} \mathrm{H}_{2} \mathrm{O}_{2}$ stock in $25 \mathrm{mM} \mathrm{NaPO}_{4}, \mathrm{pH} 7.2$, was then added, and the amount of reduced ASA in the reaction was monitored at $290 \mathrm{~nm}$ for $90 \mathrm{~s}$. The slope of $\mathrm{Abs}_{290}$ decrease was calculated from 30 to $60 \mathrm{~s}$. The decrease in $\mathrm{Abs}_{290}$ was converted to $\mathrm{nM}$ ascorbate using a molar absorbance

\footnotetext{
${ }^{1}$ Abbreviations used: ASA, ascorbic acid; ASW, artificial sea water; CAT, catalase; CFU, colony forming unit; ROS, reactive oxygen species; SOD, superoxide dismutase; $\mathrm{XO}$, xanthine oxidase.
}

coefficient of $2.8 \mathrm{mM}^{-1} \mathrm{~cm}^{-1}$. The spontaneous rate of ASA oxidation was subtracted from the $\mathrm{H}_{2} \mathrm{O}_{2}$-dependent rate, and for the data reported in Table 1, was less than $15 \%$ of the $\mathrm{H}_{2} \mathrm{O}_{2}$-dependent rate.

\section{Results and discussion}

\subsection{Effects of $X I X O$ system on viability of $P$. marinus and V. splendidus}

Superoxide was generated using the xanthine/xanthine oxidase $(\mathrm{X} / \mathrm{XO})$ system with levels of $\mathrm{XO}$ up to $1000 \mathrm{mU} / \mathrm{ml}$ (Fig. 1A). At the highest level of XO tested $(1000 \mathrm{mU} / \mathrm{ml})$, the mean viability of $P$. marinus trophozoites decreased by $17 \%$, which was not significant when analyzed by Student's $t$ test $(p=0.06)$. Although a $1000 \mathrm{mU} / \mathrm{ml}$ reaction has the potential to create $212 \mathrm{nM} /$ min superoxide, as explained in Section 2, our system produced only about $20 \%$ of the superoxide theoretically possible. Thus, we estimate that the $1000 \mathrm{mU}$ reaction produced approximately $42 \mathrm{nM} / \mathrm{min}$ superoxide. Activated human neutrophils produce from 14.9 to $26 \mathrm{nM} /$ min superoxide per $10^{6}$ cells (Bortolussi et al., 1987; Tan and Berridge, 2000). In a qualitative study, it is also reported that oyster hemocytes are relatively poor generators of reactive oxygen, as compared to fish leukocytes (Bramble and Anderson, 1998). Allowing that fish hemocytes generate no more superoxide than human neutrophils, $P$. marinus may potentially tolerate the level of superoxide created by oyster hemocytes.

In comparison to $P$. marinus, $V$. splendidus showed greater sensitivity to the $\mathrm{X} / \mathrm{XO}$ system. Treatments with $\mathrm{XO}$ at of $5,25,100$, and $200 \mathrm{mU} / \mathrm{ml}$, resulted in decreases in CFUs of $12,51,60$, and $73 \%$, respectively (Fig. 1B). Except for the $5 \mathrm{mU} / \mathrm{ml}$ treatment, all of these differences are statistically significant from the untreated control $(p<0.005)$. Published reports of the susceptibility of Vibrio spp. to $\mathrm{X} / \mathrm{XO}$ or superoxide are scarce; however, stationary phase cultures of the gram negative pathogen Listeria monocytogenes are reported to be susceptible to as little as $64 \mathrm{mU} / \mathrm{ml} \mathrm{XO}$, representing $20 \mathrm{nM} / \mathrm{min}$ superoxide, while log phase cells are resistant to this level (Bortolussi et al., 1987). V. splendidus used in our study was grown overnight on LB agar, and likely consisted primarily of stationary phase cells.

\subsection{Effects of $\mathrm{H}_{2} \mathrm{O}_{2}$ on viability of $P$. marinus and V. splendidus}

We exposed $P$. marinus trophozoites to various levels of $\mathrm{H}_{2} \mathrm{O}_{2}$ for $1 \mathrm{~h}$ and assessed viability after a $1 \mathrm{~h}$ resting period. As shown in Fig. 2A, P. marinus trophozoites showed less than $10 \%$ loss of viability with exposure to $\mathrm{H}_{2} \mathrm{O}_{2}$ up to $8 \mathrm{mM}$, although the slight reduction of viability at 4 and $8 \mathrm{mM}$ was statistically significant 

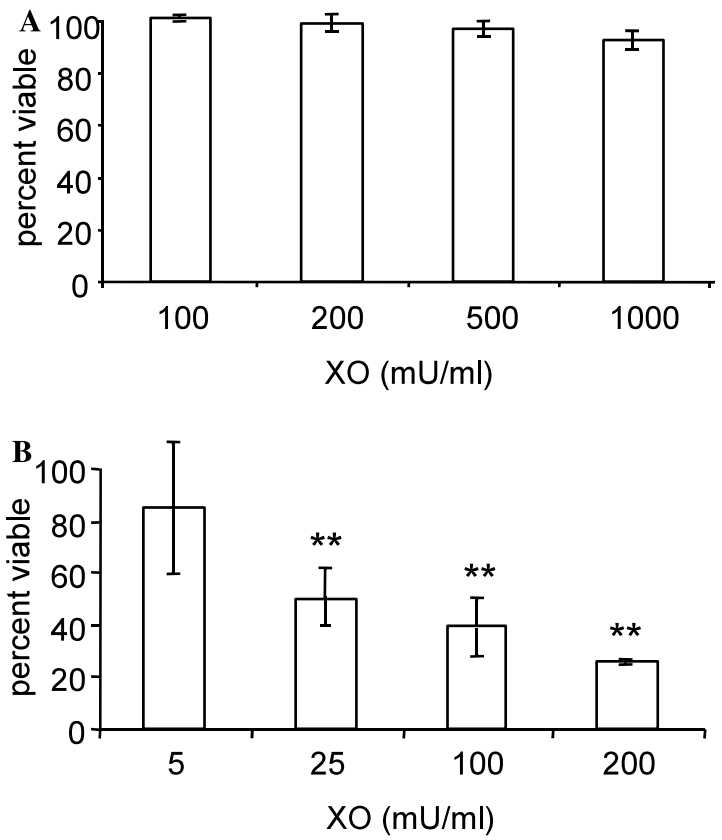

Fig. 1. Percent viability after exposure to ROS generated by the $\mathrm{X} / \mathrm{XO}$ system. (A) Percent viability of Perkinsus marinus trophozoites after a $1 \mathrm{~h}$ exposure to increasing amounts of XO. (B) Percent viability of Vibrio splendidus after a $1 \mathrm{~h}$ exposure to increasing amounts of XO. Viability measurements as in Section 2; error bars are SD. ${ }^{* *} p<0.005$ versus untreated controls.
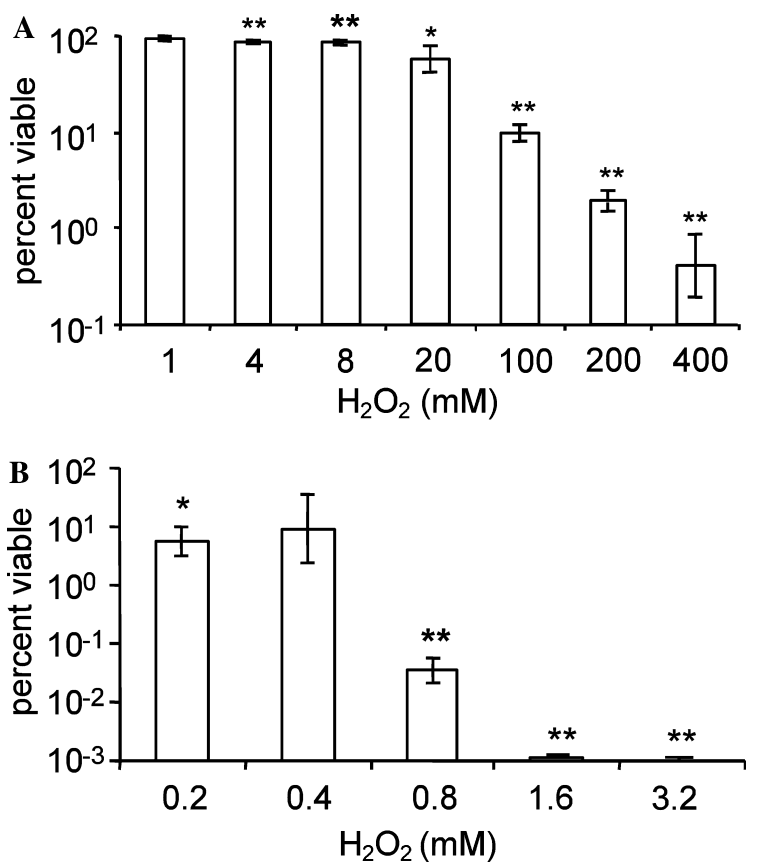

Fig. 2. Percent viability after exposure to $\mathrm{H}_{2} \mathrm{O}_{2}$. (A) Viability of Perkinsus marinus trophozoites after a $1 \mathrm{~h}$ exposure to increasing amounts of $\mathrm{H}_{2} \mathrm{O}_{2}$. (B) Viability of Vibrio splendidus after a $1 \mathrm{~h}$ exposure to increasing amounts of $\mathrm{H}_{2} \mathrm{O}_{2}$. Viability measurements as in Section 2; error bars are SD. ${ }^{*} p<<0.005,{ }^{*} p<0.05$ versus untreated controls. $(p<0.005)$. Only when the $\mathrm{H}_{2} \mathrm{O}_{2}$ concentration was raised above $100 \mathrm{mM}$ did $P$. marinus viability decrease by more than $90 \%$. Tolerance of $P$. marinus to $\mathrm{H}_{2} \mathrm{O}_{2}$ exposure appears high in comparison to the protistan parasites Toxoplasma gondii and Entamoeba histolytica, which are reported to be susceptible to exposure to 1 and $0.8 \mathrm{mM} \mathrm{H}_{2} \mathrm{O}_{2}$, respectively (Hughes et al., 1989; Murray and Cohn, 1979). Notable in the E. histolytica study was the observation that a virulent strain was slightly less susceptible to $\mathrm{H}_{2} \mathrm{O}_{2}$ than was an avirulent strain (Ghadirian et al., 1986). It is interesting to note that $T$. gondii has catalase (CAT) activity, while E. histolytica lacks this activity, as do a number of other $\mathrm{H}_{2} \mathrm{O}_{2}$-sensitive parasites (Mehlotra, 1996; Weinbach and Diamond, 1974). There is no evidence of CAT activity in P. marinus, despite efforts by us and others to detect it (Pecher and Vasta, unpublished; Chu et al., 1998).

In contrast to the $\mathrm{H}_{2} \mathrm{O}_{2}$-tolerance of $P$. marinus, as little as $0.2 \mathrm{mM} \mathrm{H}_{2} \mathrm{O}_{2}$ decreased $V$. splendidus $\mathrm{CFU}$ by over $90 \%$, and above $1 \mathrm{mM}$, CFU were lowered by over $99.99 \%(p<0.005)$. Two other marine Vibrio species, $V$. harveyi and $V$. angustum (pathogenic and free living, respectively) are reported to be highly resistant to transient exposure to $2-100 \mathrm{mM} \mathrm{H}_{2} \mathrm{O}_{2}$, especially in stationary cultures (Ostrowski et al., 2001; Vattanaviboon and Mongkolsuk, 2001). The dramatic difference between the $\mathrm{H}_{2} \mathrm{O}_{2}$ susceptibility of $V$. splendidus and these other Vibrio spp. may be explained by the fact that the $V$. harveyi and $V$. angustum studies were conducted with cell densities at least 10-fold higher than those used in this study. At high cell densities, bacterial CAT or other antioxidant enzymes have the potential to rapidly destroy $\mathrm{H}_{2} \mathrm{O}_{2}$. In separate studies on $V$. cholera, exposure of $10^{6}$ cells $/ \mathrm{ml}$ to $1 \mathrm{mM} \mathrm{H}_{2} \mathrm{O}_{2}$ resulted in greater than $99 \%$ reduction in $\mathrm{CFU}$, whereas at a 10 -fold higher cell density $V$. cholera removed the $\mathrm{H}_{2} \mathrm{O}_{2}$ from the assay medium and suffered less than $10 \%$ reduction in CFU (Schott et al., unpublished). Similar "threshold cell density" effects have been reported by others (Alcorn et al., 1994). In this study, P. marinus was tested at $2.5 \times 10^{6} \mathrm{cells} / \mathrm{ml}$. Selected experiments conducted at twofold higher and twofold lower cell densities showed no discernable difference in susceptibility (data not shown).

\subsection{Effects of hypochlorite on viability of P. marinus and $V$. splendidus}

In phagocytic cells, the enzyme myeloperoxidase MPO produces $\mathrm{HOCl}$ using $\mathrm{H}_{2} \mathrm{O}_{2}$ and chloride. In vitro, $P$. marinus trophozoites were markedly more susceptible to hypochlorite than to $\mathrm{H}_{2} \mathrm{O}_{2}$ or the $\mathrm{X} / \mathrm{XO}$ system (Fig. 3A). Exposure to only $25 \mu \mathrm{M} \mathrm{HOCl}$ reduced trophozoite viability by $42 \%$, and exposure to 50,100 , and $200 \mu \mathrm{M}$ reduced viability by 97,98 , and $99 \%$, 
respectively. In this experiment, we also observed that inclusion of the radical scavenger arginine $(10 \mathrm{mM})$ in the $50 \mu \mathrm{M} \mathrm{HOCl}$ treatment restored viability from 2 to $92 \%(p<0.005)$. The susceptibility of $V$. splendidus to $\mathrm{HOCl}$ was comparable to that of $P$. marinus: although exposure to $25 \mu \mathrm{M} \mathrm{HOCl}$ resulted in no significant decrease in CFU, exposure to 50,100 , and $200 \mu \mathrm{M}$ treatments lowered CFUs by 63, 99.9, and $99.99 \%$, respectively (Fig. 3B). Many bacterial and protistan species also show such differential sensitivity to $\mathrm{HOCl}$ over X/XO or $\mathrm{H}_{2} \mathrm{O}_{2}$ (Jepras and Fitzgeorge, 1986; Murray and Cohn, 1979), and are highly susceptible to killing by macrophage or neutrophils that produce HOCl (Ferrante et al., 1987; Vincendeau et al., 1989). The metazoan parasite Schistosoma mansoni is more susceptible to $\mathrm{H}_{2} \mathrm{O}_{2}$ than $\mathrm{HOCl}$ produced by hemocytes of the snail Biomphalaria glabrata (Hahn et al., 2001). There are reports of MPO-like activity in C. virginica hemocytes, though there are questions as to whether it is efficiently activated by exposure to live $P$. marinus (Anderson et al., 1997; Bramble and Anderson, 1998). Our in vitro data show that the product of the MPO system, $\mathrm{HOCl}$, is capable of killing $P$. marinus.

\subsection{Ability of live P. marinus to degrade hydrogen peroxide}

The low susceptibility of $P$. marinus to $\mathrm{X} / \mathrm{XO}$ and $\mathrm{H}_{2} \mathrm{O}_{2}$ raised the question of how efficient the organism is


Fig. 3. Percent viability after exposure to HOCl. (A) Viability of Perkinsus marinus trophozoites after $1 \mathrm{~h}$ exposure to increasing amounts of $\mathrm{HOCl}$. Shaded column represents a parallel treatment with both $50 \mu \mathrm{M} \mathrm{HOCl}$ and $10 \mathrm{mM}$ arginine. (B) Viability of Vibrio splendidus after $1 \mathrm{~h}$ exposure to increasing amounts of $\mathrm{HOCl}$ as in Section 2. Viability measurements as in Section 2; error bars are SD. ${ }^{* *} p<0.005$ versus untreated controls. at removing these ROS from solution. $P$. marinus is known to possess abundant SOD activity (Ahmed et al., 2003; Schott and Vasta, 2003; Wright et al., 2002), which likely converts superoxide into $\mathrm{H}_{2} \mathrm{O}_{2}$, but no mechanism for removing $\mathrm{H}_{2} \mathrm{O}_{2}$ has yet been described. In most organisms, catalase degrades $\mathrm{H}_{2} \mathrm{O}_{2}$ to water and molecular oxygen. Many organisms also possess glutathione peroxidase, which reduces $\mathrm{H}_{2} \mathrm{O}_{2}$ to water at the expense of reduced glutathione. In plants, ascorbatedependent peroxidase (APX) is known to contribute to $\mathrm{H}_{2} \mathrm{O}_{2}$ removal (Amako et al., 1994). APX has also been identified in at least one protist (Boveris et al., 1980; Wilkinson et al., 2002).

We investigated the ability of suspensions of live $P$. marinus and $V$. splendidus to degrade $\mathrm{H}_{2} \mathrm{O}_{2}$ over a $1 \mathrm{~h}$ period, taking measurements at three intervals, and calculating the rate of $\mathrm{H}_{2} \mathrm{O}_{2}$ consumption per $10^{8}$ cells for each interval. P. marinus removed 19.9, 21.9, and $21.3 \mathrm{nmol}$ of $\mathrm{H}_{2} \mathrm{O}_{2}$ per $10^{8}$ cells $/ \mathrm{h}$ at incubation times of 25, 40, and $60 \mathrm{~min}$ (Fig. 4). In comparison, $V$. splendidus removed 35, 30, and $24 \mathrm{nmol}$ per $10^{8} \mathrm{cells} / \mathrm{h}$ at these three timepoints. We note that the rate of $\mathrm{H}_{2} \mathrm{O}_{2}$ removal by $P$. marinus remained constant over the $1 \mathrm{~h}$ assay period, while the $\mathrm{H}_{2} \mathrm{O}_{2}$ removal rate by $V$. splendidus diminished by more than $30 \%$.

The relative abilities of $P$. marinus and $V$. splendidus to remove $\mathrm{H}_{2} \mathrm{O}_{2}$ appear incongruent with their susceptibilities to it. Indeed, during the assays to measure $\mathrm{H}_{2} \mathrm{O}_{2}$ removal, conducted at $75 \mu \mathrm{M} \mathrm{H}_{2} \mathrm{O}_{2}$, the viability of $V$. splendidus was decreased by $99 \%$, while that of $P$. marinus dropped only $4 \%$. Multiple factors will contribute to the ability of cells to degrade $\mathrm{H}_{2} \mathrm{O}_{2}$,
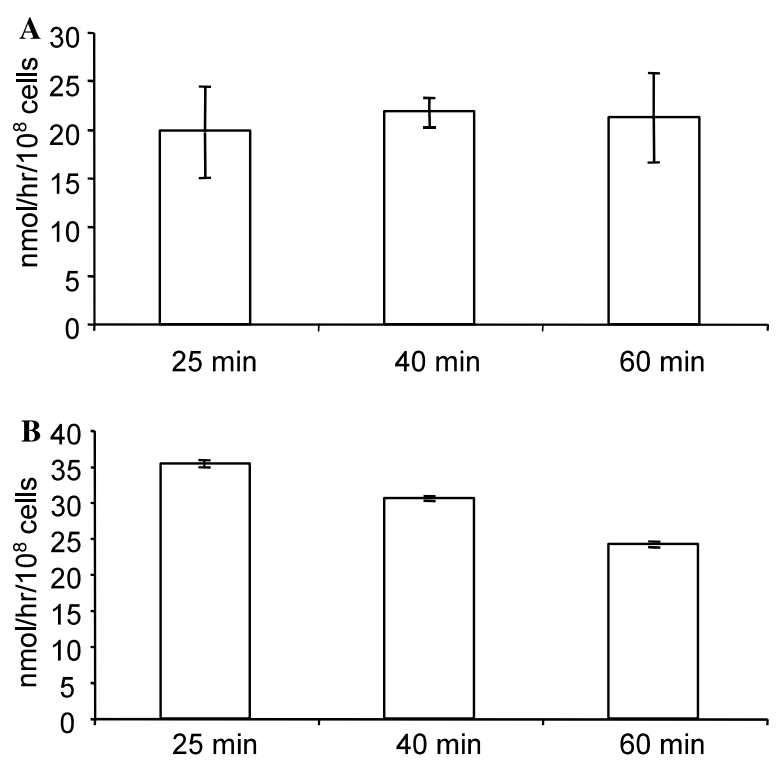

Fig. 4. Hydrogen peroxide removal by live cells. The amount of $\mathrm{H}_{2} \mathrm{O}_{2}$ removed by live cells was measured at 25,40 , and $60 \mathrm{~min}$, and the rate of $\mathrm{H}_{2} \mathrm{O}_{2}$ removal ( $\mathrm{nmol} / \mathrm{h} / 10^{8}$ cells) then calculated for each timepoint. Each timepoint is an average and SD of triplicate samples. (A) Perkinsus marinus; (B)Vibrio splendidus. 
including cell surface to volume ratio (s/v), cell wall/ membrane permeability to $\mathrm{H}_{2} \mathrm{O}_{2}$, and the compartmentalization of catalytic or peroxidatic activities. Based on published data (Gauthier and Vasta, 1993; Jiang and Chai, 1996), we estimate that cultured $P$. marinus trophozoites are approximately $65 \mu \mathrm{m}^{3}$ spheres, with a $\mathrm{s} / \mathrm{v}$ ratio of 1.2 , while Vibrio spp. are approximately $1.0 \mu \mathrm{m}^{3}$ rods with a $\mathrm{s} / \mathrm{v}$ ratio of 6.3 . Thus, the modestly higher rate of $\mathrm{H}_{2} \mathrm{O}_{2}$ removal per cell by $V$. splendidus would be a relatively much higher rate if expressed in terms of cell volume. On the other hand, slower diffusion of $\mathrm{H}_{2} \mathrm{O}_{2}$ into the much larger P. marinus cells could result in an underestimate of their internal peroxidatic potential. Although both organisms are surrounded by substantial cell walls in addition to cell membranes (Montes et al., 2002; Perkins, 1967), the relative permeability of $P$. marinus to $\mathrm{H}_{2} \mathrm{O}_{2}$, as compared to $V$. splendidus, is not known.

In Vibrio spp, catalase is located in the cytosol, and may also be present in the periplasm (Yumoto et al., 2000). Niether the identity, nor the location, of potential $\mathrm{H}_{2} \mathrm{O}_{2}$-degrading activities of $P$. marinus is known. The two $P$. marinus SODs, however, are located in different compartments, consistent with their N-terminal leader sequences: PmSOD1 in the mitochondrion, and PmSOD2 possibly in unidentified structures/vesicles near the cell periphery (Schott and Vasta, 2003). Bacteria also have SODs targeted to both cytosol and periplasm (Korshunov and Imlay, 2002). We confirmed that like other Vibrio spp., crude extracts of $V$. splendi$d u s$ possesses abundant catalase activity, using standard methods (Aebi, 1984; Ostrowski et al., 2001; Vattanaviboon and Mongkolsuk, 2001). In contrast, we have been unable to detect CAT activity or identify CAT gene sequences in $P$. marinus, despite extensive biochemical detection efforts using $P$. marinus extracts and extensive gene detection efforts using degenerate oligonucleotidebased amplifications from genomic P. marinus DNA (Pecher and Vasta, unpublished).

\subsection{Peroxidase activity of $P$. marinus and $V$. splendidus extracts}

The inability to detect catalase activity in P. marinus extracts motivated a search for alternative peroxidatic activities. Preliminary efforts to detect glutathione peroxidase were unsuccessful; however, an uncommon activity, reported in another catalase-negative protistan parasite, Trypanosoma cruzi, is ascorbate-dependent peroxidase (APX) (Boveris et al., 1980; Wilkinson et al., 2002). APX activity may be easily overlooked, because the preservation of APX activity in cell extracts requires the constant presence of ascorbate. We dialyzed soluble cell extracts $(1 \mathrm{mg} / \mathrm{ml})$ of $P$. marinus and $V$. splendidus in buffer containing $1 \mathrm{mM}$ ascorbate, and assessed their ability to remove $\mathrm{H}_{2} \mathrm{O}_{2}$ from solution with the $\mathrm{FOX}$ assay. As before, the rate of $\mathrm{H}_{2} \mathrm{O}_{2}$ removal was measured at 20,40, and $60 \mathrm{~min}$. The $P$. marinus extract removed 3.0, 2.9, and $3.5 \mathrm{nmol}$ of $\mathrm{H}_{2} \mathrm{O}_{2} / \mathrm{h} / \mathrm{mg}$ protein, while $V$. splendidus extract removed 16.4, 12.1, and $8.3 \mathrm{nmol} / \mathrm{h} / \mathrm{mg}$ protein (Figs. 5A and B). It should be considered that as with live cells, the dialyzed extract of $P$. marinus displays a constant level of peroxidatic activity, while the activity in the $V$. splendidus extract decreased by nearly half over the course of $1 \mathrm{~h}$.

It is notable that the $\mathrm{H}_{2} \mathrm{O}_{2}$ degrading activity of $V$. splendidus decreased over time. There are reports that some CAT activities are susceptible to inactivation by high concentrations of $\mathrm{H}_{2} \mathrm{O}_{2}$ (e.g., DeLuca et al., 1995), but whether this phenomenon is relevant to our observations has not been confirmed.

\subsection{Evidence of ascorbate peroxidase in $P$. marinus extracts}

If the removal of $\mathrm{H}_{2} \mathrm{O}_{2}$ from solution is partly or wholly due to the action of APX, then it should be directly reflected by an $\mathrm{H}_{2} \mathrm{O}_{2}$-dependent oxidization of ascorbate. To investigate this, we conducted standard APX assays using a spectrophotometric method that follows the oxidation of ascorbate (Abs at $290 \mathrm{~nm}$ ). In a representative experiment (Table 1), there was significant APX activity in $P$. marinus extracts $\left(\Delta A_{290}\right.$ of $\left.-0.062 \mathrm{~min}^{-1}\right)$, but not in $V$. splendidus extracts $\left(\Delta A_{290}\right.$ of $\left.+0.001 \mathrm{~min}^{-1}\right)$. When expressed in terms of ascorbate oxidation per mg protein, the rate observed in P. marinus extracts is $2430 \mathrm{nmol} / \mathrm{h} / \mathrm{mg}$ protein. This is nearly three orders of magnitude greater than the measured
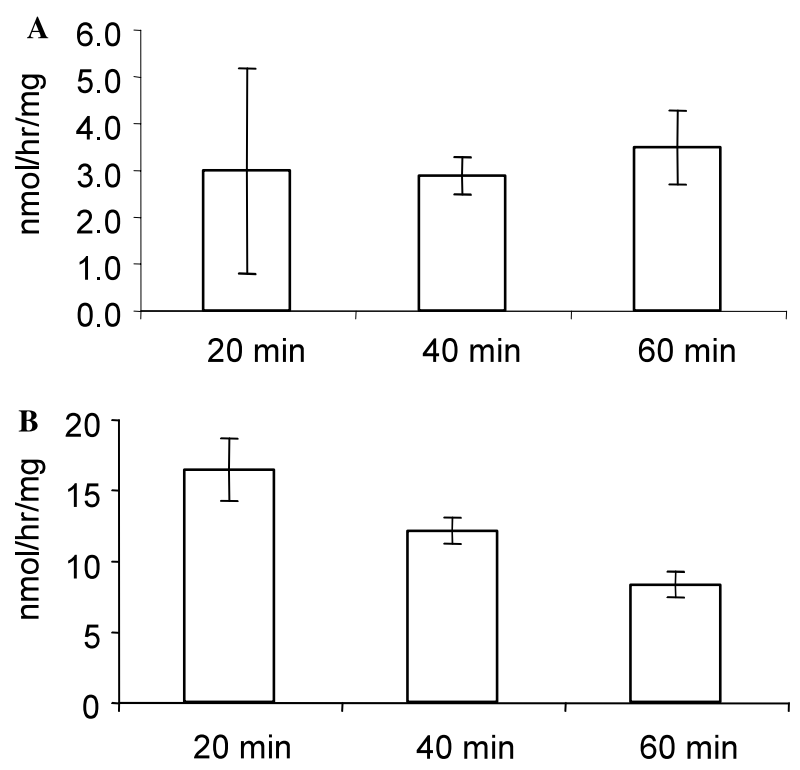

Fig. 5. Hydrogen peroxide removal by dialyzed extracts. The amount of $\mathrm{H}_{2} \mathrm{O}_{2}$ removed by dialyzed cell extracts was measured at 25,40 , and $60 \mathrm{~min}$, and the rate of $\mathrm{H}_{2} \mathrm{O}_{2}$ removal ( $\mathrm{nmol} / \mathrm{h} / \mathrm{mg}$ protein) then calculated for each timepoint. Each timepoint represents the average and SD of triplicate samples. (A) Perkinsus marinus; (B) Vibrio splendidus. 
Table 1

Detection of ascorbate peroxidase activity in dialyzed extracts ${ }^{\mathrm{a}}$

\begin{tabular}{|c|c|c|c|}
\hline Source of extract & $\Delta A_{290}$ extract only ${ }^{\mathrm{b}}$ & $\Delta A_{290}$ extract with $\mathrm{H}_{2} \mathrm{O}_{2}^{\mathrm{b}}$ & $\Delta$ [ascorbate] $(\mathrm{nmol} / \mathrm{h} / \mathrm{mg})$ \\
\hline Perkinsus marinus & -0.008 & -0.062 & 2430 \\
\hline Vibrio splendidus & +0.003 & +0.001 & 0 \\
\hline
\end{tabular}

rate of $\mathrm{H}_{2} \mathrm{O}_{2}$ destruction in the assays depicted in Fig. 4, which were conducted using the same extracts as used for APX assays. There may be several factors contributing to this discrepancy. First, the APX assays were conducted for only $2 \mathrm{~min}$, following a $30 \mathrm{~s}$ delay period for mixing reagents. When APX assays were extended for $20 \mathrm{~min}$, the rate of ascorbate oxidation diminished by as much as $50 \%$ (not shown), suggesting that the contribution of APX to long-term $\mathrm{H}_{2} \mathrm{O}_{2}$ removal may be transient. Second, because it is typical for ascorbate to oxidize over time as a result of dissolved oxygen in the buffer and exposure to light, the ascorbate present in dialyzed extracts is partially oxidized, and oxidized ascorbate cannot serve as an electron donor for reduction of $\mathrm{H}_{2} \mathrm{O}_{2}$. It is possible that in addition to APX activity, $P$. marinus possesses another, less transient, activity that removes $\mathrm{H}_{2} \mathrm{O}_{2}$ more slowly.

In conclusion, the results presented here support the hypothesis that, like a number of other pathogens that are resistant to intra-phagocytic killing, P. marinus is relatively tolerant to selected ROS (Ghadirian et al., 1986). In spite of lacking CAT activity, P. marinus is over 100 times more tolerant than $V$. splendidus to the superoxide generating system of $\mathrm{X} / \mathrm{XO}$, and over 100 times more tolerant to $\mathrm{H}_{2} \mathrm{O}_{2}$. In contrast, the susceptibility of $P$. marinus to $\mathrm{HOCl}$ is equivalent to the sensitivity displayed by $V$. splendidus. To our knowledge, there are no reported enzymes that detoxify $\mathrm{HOCl}$ in any system, although there are other biologically relevant mechanisms for alleviating the toxic effects of $\mathrm{HOCl}$, such as the radical scavengers arginine and ascorbate (Ferrante et al., 1987; Hu et al., 1993). Preliminary measurements show that P. marinus extracts contain at least $2 \mathrm{mM}$ ascorbate (data not shown; Schaus et al., 1986). It remains an open question as to whether ascorbate serves as a $\mathrm{HOCl}$ scavenger as well as a cofactor for the $\mathrm{H}_{2} \mathrm{O}_{2}$-destroying enzyme, APX. In a broader context, the findings of this study do not exclude the possibility that other factors secreted by $P$. marinus may contribute to directly suppress the generation of ROS by oyster hemocytes, as suggested by other authors (Anderson, 1999).

\section{Acknowledgments}

We thank Drs. R. Colwell and A. Huq (COMB, $\mathrm{UMBI}$ ) for providing Vibrio strains. This work was supported by Grant NA06RG0101 awarded by NOAA, Oyster Disease Research Program, Sea Grant College.

\section{References}

Aebi, H., 1984. Catalase in vitro. Methods Enzymol. 105, 121-126.

Ahmed, H., Schott, E.J., Silva, A.M., Vasta, G.R., 2003. Superoxide dismutases from the oyster parasite Perkinsus marinus: purification, biochemical characterization, and development of a plate microassay for activity. Anal. Biochem. 318, 132-141.

Alcorn, T.M., Zheng, H.Y., Gunther, M.R., Hassett, D.J., Cohen, M.S., 1994. Variation in hydrogen peroxide sensitivity between different strains of Neisseria gonorrhoeae is dependent on factors in addition to catalase activity. Infect. Immun. 62, 21362140.

Amako, K., Chen, G.-X., Asada, K., 1994. Separate assays specific for ascorbate peroxidase and guaiacol peroxidase and for the chloroplastic and cytosolic isozymes of ascorbate peroxidase in plants. Plant Cell Physiol. 35, 497-504.

Anderson, R.S., 1999. Perkinsus marinus secretory products modulate superoxide anion production by oyster (Crassostrea virginica) haemocytes. Fish Shellfish Immunol. 9, 51-60.

Anderson, R.S., Brubacher, L.L., Calvo, L.M., Burreson, E.M., Unger, M.A., 1997. Effect of in vitro exposure to tributyltin on generation of oxygen metabolites by oyster hemocytes. Environ. Res. 74, 84-90.

Anderson, R.S., Paynter, K.T., Burreson, E.M., 1992. Increased reactive oxygen intermediate production by hemocytes withdrawn from Crassostrea virginica infected with Perkinsus marinus. Biol. Bull. Mar. Biol. Lab. Woods Hole 183, 476-481.

Azevedo, C., 1989. Fine structure of Perkinsus atlanticus n. sp. (Apicomplexa, Perkinsea) parasite of the clam Ruditapes decussatus from Portugal. J. Parasitol. 75, 627-635.

Birnboim, H.C., Sandhu, J., 1997. Levels of DNA strand breaks and superoxide in phorbol ester-treated human granulocytes. J. Cell. Biochem. 66, 219-228.

Bortolussi, R., Vandenbroucke-Grauls, C.M., van Asbeck, B.S., Verhoef, J., 1987. Relationship of bacterial growth phase to killing of Listeria monocytogenes by oxidative agents generated by neutrophils and enzyme systems. Infect. Immun. 55, 31973203.

Boveris, A., Sies, H., Martino, E.E., Docampo, R., Turrens, J.F., Stoppani, A.O., 1980. Deficient metabolic utilization of hydrogen peroxide in Trypanosoma cruzi. Biochem. J. 188, 643-648.

Bramble, L.H., Anderson, R.S., 1998. A comparison of the chemiluminescent response of Crassostrea virginica and Morone saxatilis phagocytes to zymosan and viable Listonella anguillarum. Dev. Comp. Immunol. 22, 55-61.

Brawn, K., Fridovich, I., 1981. DNA strand scission by enzymically generated oxygen radicals. Arch. Biochem. Biophys. 206, 414-419.

Brugerolle, G., 2002. Cryptophagus subtilis: a new parasite of cryptophytes affiliated with the Perkinsozoa lineage. Eur. J. Protistol. 37, 379-390. 
Chu, F.L., Volety, A.K., Armknecht, S., 1998. Antioxidant enzymes, potential virulent factors, in different strains of the oyster protozoan parasite, Perkinsus marinus. J. Shellfish Res. 17.

DeLuca, D.C., Dennis, R., Smith, W.G., 1995. Inactivation of an animal and a fungal catalase by hydrogen peroxide. Arch. Biochem. Biophys., 129-134.

Dukan, S., Belkin, S., Touati, D., 1999. Reactive oxygen species are partially involved in the bacteriocidal action of hypochlorous acid. Arch. Biochem. Biophys. 367, 311-316.

Ferrante, A., Hill, N.L., Abell, T.J., Pruul, H., 1987. Role of myeloperoxidase in the killing of Naegleria fowleri by lymphokine-altered human neutrophils. Infect. Immun. 55, 10471050.

Gardner, P.R., Fridovich, I., 1991. Superoxide sensitivity of the Escherichia coli aconitase. J. Biol. Chem. 266, 19328-19333.

Gauthier, J.D., Vasta, G.R., 1993. Continuous in vitro culture of the eastern oyster parasite Perkinsus marinus. J. Invertebr. Pathol. 62, 321-323.

Ghadirian, E., Somerfield, S.D., Kongshavn, P.A., 1986. Susceptibility of Entamoeba histolytica to oxidants. Infect. Immun. 51, 263-267.

Goggin, C.L., Barker, S.C., 1993. Phylogenetic position of the genus Perkinsus (Protista, Apicomplexa) based on small subunit ribosomal RNA. Mol. Biochem. Parasitol. 60, 65-70.

Greger, E.A., Drum, A.S., Elston, R.A., 1995. Measurement of oxidative activity in hemocytes of the Pacific razor clam, Siliqua patula, and the oyster, Crassostrea gigas, using lucigenin- and luminol-dependent chemiluminescence. J. Invertebr. Pathol. 65, 48-60.

Hahn, U.K., Bender, R.C., Bayne, C.J., 2001. Killing of Schistosoma mansoni sporocysts by hemocytes from resistant Biomphalaria glabrata: role of reactive oxygen species. J. Parasitol. 87, 292299.

Hu, M.L., Louie, S., Cross, C.E., Motchnik, P., Halliwell, B., 1993. Antioxidant protection against hypochlorous acid in human plasma. J. Lab. Clin. Med. 121, 257-262.

Hughes, H.P., Boik, R.J., Gerhardt, S.A., Speer, C.A., 1989. Susceptibility of Eimeria bovis and Toxoplasma gondii to oxygen intermediates and a new mathematical model for parasite killing. J. Parasitol. 75, 489-497.

Jepras, R.I., Fitzgeorge, R.B., 1986. The effect of oxygen-dependent antimicrobial systems on strains of Legionella pneumophila of different virulence. J. Hyg. (Lond.) 97, 61-69.

Jiang, X., Chai, T.J., 1996. Survival of Vibrio parahaemolyticus at low temperatures under starvation conditions and subsequent resuscitation of viable, nonculturable cells. Appl. Environ. Microbiol. 62, $1300-1305$.

Jiang, Z.Y., Hunt, J.V., Wolff, S.P., 1992. Ferrous ion oxidation in the presence of xylenol orange for detection of lipid hydroperoxide in low density lipoprotein. Anal. Biochem. 202, 384-389.

Korshunov, S.S., Imlay, J.A., 2002. A potential role for periplasmic superoxide dismutase in blocking the penetration of external superoxide into the cytosol of Gram-negative bacteria. Mol. Microbiol. 43, 95-106.

La Peyre, J.F., Chu, F.L., Vogelbein, W.K., 1995. In vitro interaction of Perkinsus marinus merozoites with eastern and Pacific oyster hemocytes. Dev. Comp. Immunol. 19, 291-304.

Lacoste, A., Jalabert, F., Malham, S., Cueff, A., Gelebart, F., Cordevant, C., Lange, M., Poulet, S.A., 2001. A Vibrio splendidus strain is associated with summer mortality of juvenile oysters Crassostrea gigas in the Bay of Morlaix (North Brittany, France). Dis. Aquat. Organ 46, 139-145.

Lester, R.J.G., Davis, G.H.G., 1981. A new Perkinsus species (Apicomplexa, Perkinsea) from the abalone Haliotis ruber. J. Invertebr. Pathol. 37, 181-187.

Levine, N.D., 1978. Perkinsus gen.n., other new taxa in the protozoan phylum Apicomplexa. J. Parasitol. 64, 549.
Mehlotra, R.K., 1996. Antioxidant defense mechanisms in parasitic protozoa. Crit. Rev. Microbiol. 22, 295-314.

Meyers, J.A., Burreson, E.M., Barber, B.J., Mann, R., 1991. Susceptibility of diploid and triploid pacific oysters Crassostrea gigas (Thunberg, 1793) and eastern oysters, Crassostrea virginica (Gmelin, 1791), to Perkinsus marinus. J. Shellfish Res. 10, 433-437.

Montes, J.F., Durfort, M., Llado, A., Garcia-Valero, J., 2002. Characterization and immunolocalization of a main proteinaceous component of the cell wall of the protozoan parasite Perkinsus atlanticus. Parasitology 124, 477-484.

Murray, H., Cohn, Z., 1979. Macrophage oxygen-dependent antimicrobial activity. I. Susceptibility of Toxoplasma gondii to oxygen intermediates. J. Exp. Med. 150, 938-949.

Nakamura, M., Mori, K., Inooka, S., Nomura, T., 1985. In vitro production of hydrogen peroxide by the amoebocytes of the scallop, Patinopecten yessoensis (Jay). Dev. Comp. Immunol. 9, 407-417.

Norén, F., Moestrup, Ø., Rehnstam-Holm, A.-S., 1999. Parvilucifera infectans Norén et Moestrup gen. et sp. nov. (Perkinsozoa phylum nov.): a parasitic flagellate capable of killing toxic microalgae. Vet. Parasitol. 35, 233-254.

Ohno, Y.G., Gallin, J.I., 1985. Diffusion of extracellular hydrogen peroxide into intracellular compartments of human neutrophils. Studies utilizing the inactivation of myeloperoxidase by hydrogen peroxide and azide. J. Biol. Chem. 260, 843-846.

Ostrowski, M., Cavicchioli, R., Blaauw, M., Gottschal, J.C., 2001. Specific growth rate plays a critical role in hydrogen peroxide resistance of the marine oligotrophic ultramicrobacterium Sphingomonas alaskensis strain RB2256. Appl. Environ. Microbiol. 67, 1292-1299.

Perkins, F.O., 1996. The structure of Perkinsus marinus (Mackin et al., 1950) Levine (1978) with comments on taxonomy and phylogeny of Perkinsus spp. J. Shellfish Res. 15, 67-87.

Perkins, F.O., Menzel, R.W., 1967. Ultrastructure of sporulation in the oyster pathogen Dermocystidinuim marinum. J. Invertebr. Pathol. 9, 205-229.

Rotman, B., Papermaster, B.W., 1966. Membrane properties of living mammalian cells as studied by enzymatic hydrolysis of fluorogenic esters. Proc. Natl. Acad. Sci. USA 55, 134-141.

Saldarriaga, J., Taylor, F., Keeling, P., Cavalier-Smith, T., 2001. Dinoflagellate nuclear SSU rRNA phylogeny suggests multiple plastid losses and replacements. J. Mol. Evol. 53, 204-213.

Schott, E.J., Vasta, G.R., 2003. The PmSOD1 gene of the protistan parasite Perkinsus marinus complements the $\operatorname{sod} 2 \Delta$ mutant of Saccharomyces cerevisiae, and directs an iron superoxide dismutase to mitochondria. Mol. Biochem. Parasitol. 126, 81-92.

Schaus, E.E., Kutnink, M.A., O’Connor, D.K., Omaye, S., 1986. A comparison of leukocyte ascorbate levels measured by the 2,4dinitrophenylhydrazine method with high-performance liquid chromatography. Biochem. Med. Metab. Biol. 36, 369-376.

Siddal, M.E., Reece, K.S., Graves, J.E., Burreson, E.M., 1997. Total evidence refutes the inclusion of Perkinsus species in the phylum Apicomplexa. Parasitology 155, 165-176.

Takahashi, K., Mori, K., 2000. NADPH oxidase-like activity in hemocytes of the Pacific oyster Crassostrea gigas. Fish Pathol. 35, $15-19$.

Tan, A.S., Berridge, M.V., 2000. Superoxide produced by activated neutrophils efficiently reduces the tetrazolium salt, WST-1 to produce a soluble formazan: a simple colorimetric assay for measuring respiratory burst activation and for screening antiinflammatory agents. J. Immunol. Methods 238, 59-68.

Vattanaviboon, P., Mongkolsuk, S., 2001. Unusual adaptive, cross protection responses and growth phase resistance against peroxide killing in a bacterial shrimp pathogen, Vibrio harveyi. FEMS Microbiol. Lett. 200, 111-116.

Vincendeau, P., Daulouede, S., Veyret, B., 1989. Role of hypochlorous acid in Trypanosoma musculi killing by phagocytes. Parasitology 98 (Part 2), 253-257. 
Vissers, M.C., Stern, A., Kuypers, F., van den Berg, J., Winterbourn, C.C., 1994. Membrane changes associated with lysis of red blood cells by hypochlorous acid. Free Radic. Biol. Med. 16, 703-712.

Volety, A.K., Chu, F.L., 1995. Suppression of chemiluminescence of eastern oyster (Crassostrea virginica) hemocytes by the protozoan parasite Perkinsus marinus. Dev. Comp. Immunol. 19, 135-142.

Weinbach, E.C., Diamond, L.S., 1974. Entamoeba histolytica. I. Aerobic metabolism. Exp. Parasitol. 35, 232-243.

Wilkinson, S.R., Meyer, D.J., Taylor, M.C., Bromley, E.V., Miles, M.A., Kelly, J.M., 2002. The Trypanosoma cruzi enzyme TcGPXI is a glycosomal peroxidase and can be linked to trypanothione reduction by glutathione or tryparedoxin. J. Biol. Chem. 277, 17062-17071.

Wright, A., Ahmed, H., Gauthier, J., Silva, A., Vasta, G., 2002. cDNA cloning and characterization of two iron superoxide dismutases from the oyster pathogen Perkinsus marinus. Mol. Biochem. Parasitol. 123, 73-77.

Yumoto, I., Ichihashi, D., Iwata, H., Istokovics, A., Ichise, N., Matsuyama, H., Okuyama, H., Kawasaki, K., 2000. Purification and characterization of a catalase from the facultatively psychrophilic bacterium Vibrio rumoiensis $\mathrm{S}-1(\mathrm{~T})$ exhibiting high catalase activity. J. Bacteriol. 182, 1903-1909. 